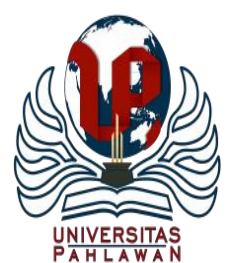

JURNAL BASICEDU

Volume 5 Nomor 3 Tahun 2021 Halaman 1604 - 1616

Research \& Learning in Elementary Education

https://jbasic.org/index.php/basicedu

\title{
Education Environment and the Impact of Pandemic Covid-19 in Student Perspective
}

\author{
Bahagia $^{1 凶}$, Fachruddin Majeri Mangunjaya ${ }^{2}$, Rimun Wibowo $^{3}, Z^{\text {Zulkifli Rangkuti }}{ }^{4}$ \\ Universitas Ibn Khaldun Bogor, Indonesia ${ }^{1}$ \\ Universitas Nasional, Indonesia ${ }^{2}$ \\ STIMA IMMI Jakarta, Indonesia ${ }^{3,4}$ \\ E-mail: $\underline{\text { bahagiagia59@yahoo.co.id }}{ }^{1}, \underline{\text { fmangunjaya@ civitas.unas.ac.id }}{ }^{2},{\underline{\text { rimunwibowo@ } @ \text { gmail.com }^{3}}}$ \\ zrangkuti@gmail.com ${ }^{4}$
}

\begin{abstract}
Abstrak
Tujuan dari penelitian ini yaitu bencana COVID-19 memberikan pembelajaran atau pendidikan lingkungan hidup secara alami kepada manusia termasuk menidik manusia ramah iklim dan perilaku rendah emisi, hemat energi, hemat air, dan mengakaui kemampuan alam semesta. Tujuan yang lain yaitu untuk menemukan dampak COVID-19 secara sosial, agama dan psikologi bahwa mahasiswa pada universitas Ibn Khaldun Bogor. Pendekatan metode penelitian menggunakan pendekatan kualitatif deskriptif. Data dikumpulkan dengan wawancara mendalam dengan ketua kelas mahasiswa semester VI. Sampel dipilih melalui teknik purposive. Hasilnya diteliti dengan cermat melalui teknik triangulasi dan triangulasi sumber. Hasil penelitian menunjukkan bahwa mahasiswa memiliki pandangan bahwa kedatangan COVID-19 telah mengajarkan manusia untuk berperilaku ramah kepada iklim karena dengan adanya COVID-19 maka mahasiswa tidak lagi kekampus, dosen dan juga officer kampus. Cara ini tergolong tindakan untuk menurunkan gas emisi kaca sebagai penyebab global warming. Selain itu, energi dan air digunakan sangat sedikit dan bahkan pada awal lockdown maka sumberdaya alam ini tidak digunakan sehingga mendidik manusia untuk hemat terhadap energi dan air melalui kampus. Penggunaan energi juga menyebabkan masalah iklim sehingga dengan hemat dapat mengurangi emisi. Setelah itu, manusia diajarkan untuk hidup bersih sebab untuk menanggulangi bencana ini maka manusia harus menjaga kebersihan lingkungan, diri dan tempat ibadah. Kemudian, wabah COVID-19 berdampak secara sosial sebab mahasiswa tidak lagi menjalin face-to face dengan mahasiswa yang lain, mengganggu kegiatan ibadah seperti agama dan juga membuat mahasiswa stress secara psikologi.
\end{abstract}

Kata Kunci: COVID-19, Iklim, Lingkungan, Pendidikan, Mahasiswa

\begin{abstract}
There are several objectives of this research, namely the COVID-19 disaster to provide natural environmental learning or education to humans, including educating people in climate-friendly and low-emission behavior, saving energy, saving water, and recognizing the ability of the universe. Another goal is to find the social, religious, and psychological impact of COVID-19 that students at Ibn Khaldun University Bogor. The research method approach used a descriptive qualitative approach. Data were collected by in-depth interviews with the class leader of semester VI students. The sample was selected through a purposive technique. The results were scrutinized through triangulation and source triangulation techniques. The results show that students have the view that the arrival of COVID-19 has taught humans to behave friendly to the climate because with the presence of COVID-19, students are no longer at the campus, lecturers, and campus officers. This method is classified as an action to reduce glass emissions as a cause of global warming. In addition, energy and water are used very little, and even at the beginning of the lockdown, these natural resources were not used, thereby educating people to save energy and water through the campus. The use of energy also causes climate problems so that it can economically reduce emissions. After that, humans are taught to live cleanly because to cope with this disaster, humans must maintain the cleanliness of the environment, themselves, and places of worship. Then, the COVID-19 outbreak has a social impact because students no longer have face-to-face contact with other students, disrupt religious activities such as religion, and also make students psychologically stressed.
\end{abstract}

Keywords: COVID-19, Climate, Environment, Education, Student

Copyright (c) 2021 Bahagia, Fachruddin Majeri Mangunjaya, Rimun Wibowo, Zulkifli Rangkuti

Corresponding author:

Email : bahagiagia59@yahoo.co.id

DOI : https://doi.org/10.31004/basicedu.v5i3.957

ISSN 2580-3735 (Media Cetak)

ISSN 2580-1147 (Media Online)

Jurnal Basicedu Vol 5 No 3 Tahun 2021 p-ISSN 2580-3735 e-ISSN 2580-1147 
1605 Education Environment and the Impact of Pandemic Covid-19 in Student Perspective - Bahagia, Fachruddin Majeri Mangunjaya, Rimun Wibowo, Zulkifli Rangkuti

DOI: https://doi.org/10.31004/basicedu.v5i3.957

\section{INTRODUCTION}

Various adaptations have been made by lecturers to teach at universities. With online learning, lecturers have the flexibility to study time, can study anytime and anywhere. Students can interact with lecturers using several learning applications / LMS such as classrooms, video conferences, live chat, zoom, or via the WhatsApp group (Solikhah \& Suripah, 2021). Ratunuman et al., (2021) said that the psychological impacts found were anxiety, depression, stress, post-traumatic stress syndrome, and post-traumatic growth. (Jannah, 2021) said that the cause of stress that emerged during the pandemic with a bold learning process was ineffective learning methods, and the conclusions that emerged as a result of the conceptual concept of learning applied in face-to-face learning did not work well. Lubis, Ramadhani \& Rasyid (2021) students experienced the most academic stress in the medium category, namely 80 students (39.2\%). Academic stress in the high category was 55 people $(27 \%)$, the low category was 48 people $(21 \%)$, the very high category was 14 people $(6.9 \%)$, and the very low category was 11 people $(5.4 \%)$. This means that students feel quite heavy pressure while carrying out online learning during the Covid19 pandemic. Female students, volunteers, first year, residence, viral infection, and various other factors are associated with existing psychological symptoms.

Angelica \& Hemme, (2021) most of the students were at normal stress levels, a small proportion at mild, moderate, severe levels, and very little at very severe levels. Most of the students utilized emotion-focused coping and a small proportion utilized problem-focused coping or equally utilized the two coping strategies. There are various psychological impacts experienced by students during the COVID-19 pandemic. Besides, the main obstacle in the learning process is the lack of internet connection/data signals in several areas where students live, which makes online lectures laggard and less attractive (Santoso, 2021). Another adverse impact is students who were at a low online shopping consumptive behavior level were $47.3 \%, 51.5 \%$ moderate, and $1.2 \%$ high. It can be concluded that the online shopping consumptive behavior during the pandemic was in the moderate category, namely $51.5 \%$ (Fernando \& Guspa, 2021). Conversely, the outbreak of COVID-19 has some benefits including virtual learning has a positive effect on student attitudes. The students are showing enthusiasm in their studies, and they welcome distance learning in the current COVID-19 pandemic. Most students like online teaching because it is a new and exciting experience for them. When studying online, students seem very excited and comfortable (Noviarini, 2021).

The impact of the COVID 19 outbreak affects the reduction of gas emissions in the universe as a cause of global warming. Directly, the COVID-19 outbreak causes the natural environment to be clean and free from various pollutants, especially the pollution caused by human activities, starting from being free from factory fumes, vehicles, and saving energy in energy use. Other activities in the world of education, starting from the use of electronic devices, have also decreased. Chapman \& Tsuji, (2020) said that short term outcomes of the COVID-19 pandemic have included improved air quality and reduced carbon dioxide (CO2) and other greenhouse gas emissions, while long term repercussions may include disruption to joint international research efforts, the creation of silos, and the potential for internalizing efforts toward national rather than global goals. The finding has been bolstered that pandemic situation significantly improves air quality in different cities across the world, reduces GHGs emission, lessens water pollution and noise, and reduces the pressure on the tourist destinations, which may assist with the restoration of the ecological system (Rume \& Islam, 2020).

Then, based on a critical review of 57 studies on the topic, we conclude that the COVID-19 pandemic has led to improved environmental quality. Due to COVID-19, actions taken by governments across the world have led to significant reductions in environmental pollution and improvements in environmental quality, particularly, in countries with severe COVID-19 transmission such as China, the USA, Italy, and Spain (Shakil et al., 2020). Furthermore, during the amidst corona pandemic, particularly during the lockdown phase, some positive effects were observed on the wildlife. During the lockdown phase, animals had increased and uninterrupted territory. In some areas, wild animals were seen on roads and in residential areas. Less traffic, less 
human intervention, and less pollution gave space for wildlife to thrive (Ankit et al., 2021).In addition, there are also some negative consequences of COVID-19, such as an increase of medical waste, haphazard use and disposal of disinfectants, masks, and gloves; and burden of untreated wastes continuously endangering the environment In this situation, the moderate reduction in electricity demand stemming from both direct restrictions on industry, commerce, and other activities and the overall economic downturn has had a particularly strong impact on power sector emissions (Bertram et al., 2021).

The results show emissions reduction up to $37 \%$ for PM10, PM2.5, and BC, consistent with observed from satellite images and up to $160 \%$ for NOx, CO, NMVOC, and SOx. However, the residential sector has increased its emissions by $8 \%$ for the same period. As a consequence, $3337 \mathrm{Gg}$ of CO2eq of GHG emissions were reduced, corresponding to a 20\% reduction compared to the same period in 2019 (Bolaño-Ortiz et al., 2020). Lastly, Lock-downs, quarantines, and border closures in the wake of the pandemic have led to reductions in air pollution through decreased travel and production. These positive environmental effects are likely mostly temporary but may serve as an example that changes in our way of life can have prompt positive effects on the environment and demonstrate the usefulness of travel-reducing measures such as teleconferencing (El Zowalaty et al., 2020). In this finding show that COVID-19 has the advantage to environment and climate because COVID-19 have contributed to declining the number of emission in nature as well as COVID-19 have impacted to improve the quality of environment such as it declines the percentage of pollution from human behavior.

It is the best method to conscious human that human must adjust their behavior to save the nature of the environment from devastated. It gives environmental education to human that they must continue the behavior to alleviate the damaged environment. Humans are very dependent on their environment, humans will disappear if their environment is damaged. A damaged living environment is an environment that can no longer carry out its function in supporting life (Ipin, 2017). Setyobudi \& Marsudi, (2018) wise environmental management in addition to saving and preserving the environment, can also guarantee the needs and prosperity of mankind itself. Therefore, the balance between the environment of human life and the natural environment can be disturbed by humans themselves. Meanwhile, the environment is a spatial unit with all objects, living things, and their behavior which can affect the continuity of life and welfare of humans and other living things (Agustin, 2018). The concept of population and environmental education (PKLH) is the process of cultivating community responsibility for the environment, so the community must care about environmental responsibilities that must be maintained and preserved (Sya'ban, Moh, 2018).

Jufri et al., (2019) environmental education will be more meaningful if the learning environment is close to the actual conditions, namely the environment that should be preserved and sustained. Environmental education should be based on direct experience with the surrounding environment so that in the future it is hoped that this direct experience can shape behavior, values, and habits to respect the surrounding environment. In this study, they no longer found what these experts had found. This research intends to research the topic of environmental education and the impact of COVID-19 on student behavior. There are several goals to be achieved including finding that COVID-19 can directly affect human behavior and concern so that it educates humans to be friendly to the environment starting from being friendly to the climate, realizing human position in front of nature, environmentally friendly, water-saving and energy-efficient. Another objective is to see the social, psychological, and religious impact on students.

\section{METHOD}

The research was conducted in the faculty of Islamic studies at Ibn Khaldun University Bogor, Tanah Sareal district, Bogor City, West Java. The research method used is a qualitative descriptive approach. Descriptive research is a form of research that aimed to describe the phenomenon that exists, whether a natural phenomenon or a man-made phenomenon. Descriptive research studying the problems in society, as well as the procedure applicable in the community and specific situations, including relationships, activities, attitudes, 
1607 Education Environment and the Impact of Pandemic Covid-19 in Student Perspective - Bahagia, Fachruddin Majeri Mangunjaya, Rimun Wibowo, Zulkifli Rangkuti

DOI: https://doi.org/10.31004/basicedu.v5i3.957

views, and processes, are ongoing and the effects of a phenomenon (Linarwati, Fathoni \& Minarsih, 2016). While this method is also called an artistic method because the research process is more artistic (less patterned), and is called an interpretive method because the research data is more concerned with the interpretation of the data found in the field. Qualitative research methods are often called naturalistic research methods because the research is carried out in conditions that are natural (natural setting) (Rukminingsih et al., 2020). Nurdin \& Hartati, (2019) means that data collection or phenomena filtering is carried out from reasonable conditions. With this nature, direct involvement of researchers in the field is required, in contrast to quantitative research which can be represented by other people to distribute or conduct structured interviews.

Meanwhile, descriptive research can be defined as the research was conducted to provide an overview in more detail about a symptom or phenomenon. The result at the end of the research is usually typology or patterns regarding the phenomenon that is being discussed. Descriptive research is conducted by searching for information associated with existing symptoms, described clearly the goals to be achieved, plan how to do his approach, and collect a variety of kinds of data as materials for making the report (Priyono, 2016). To select the sample, the research uses purposive technique sampling. This sampling technique is implemented because there are some pondering including the head of the class in the VI semester namely Rizky Ahmad Fauzan, Ibadurrahman, Abdul Aziz, and Bayu Rizky. The sample is collected because the researcher deems that they act as chairman in class. After all, all the students in Islamic studies particularly for VI semester students trust that they can lead the class. Meaning that they can answer the question which is proper to the goal of research. The person can be categorized as the person who has the widest knowledge and skill compared to another person in the member in the class.

There are several data that the researcher intends to investigate through in-depth-interview with all of the head people in class such as the impact of covid-19 on human education, especially for environmental education. Covid-19 plays a pivotal role in declining the emission of gases in the natural environment because the lecture, a student at Ibn Khaldun University, and another officer at the university must be completed their work from home. It leads to produce some advantage including save energy, water, and reduce the usage of some campus facilities which it can be caused adverse effects to human life and environment. Researchers ask the student about this from their perspective. The other important that the researcher would like to gather is to understand the unworthiness of the outbreak to the student at Ibn Khaldun University especially in Islamic studies about their social effect, physiological impact, and religion. The data which have been gathered from in-depthinterview must be combined with another method like observation and documentation. Observation must be conducted because to see the location and the real action of cities. Once the data from some of the methods have been gathered, the data must be analyzed by triangulation data.

Harahap, (2016) said that the purpose of triangulation is to check the correctness of certain data by comparing it with data obtained from other sources at various phases of research in the field at different times. Triangulation can also be done by comparing the results of two or more researchers using different techniques. This also prevents the danger of subjectivity. In this research, the researcher is assisted by other researchers to conduct the same interview as the original researcher to see the consistency of the respondents' answers to the questions asked by the researcher. Finally, synchronous data were obtained between in-depth interviews conducted by the researcher and other researchers who were instructed by the researcher to check the data in more depth. Even data collection is also carried out with differences in time (morning, daylight, and evening). The reason is that respondents are fresher in the morning so that the interviews were conducted at various times but the results still got the same answers. While the triangulation technique is to exert a variety of ways. In this research, the combination from numerous sources including in-depth-interview, observation, and documentation can be reliable data. 
1608 Education Environment and the Impact of Pandemic Covid-19 in Student Perspective - Bahagia, Fachruddin Majeri Mangunjaya, Rimun Wibowo, Zulkifli Rangkuti

DOI: https://doi.org/10.31004/basicedu.v5i3.957

\section{RESULT AND DISCUSSION}

Environmental education can be interpreted as chasing people who are not only limited to formal education but also because nature gives human awareness. Environmental education is an effort to change behavior and attitudes carried out by various parties or elements of society which aims to increase knowledge, skills, and public awareness of environmental values and environmental issues which in turn can move the community to take an active role in conservation and safety efforts environment for the benefit of present and future generations (Ipin, 2017). The events that occur in the form of natural disasters and a sustainable living environment can influence human behavior and attitudes towards the environment. For humans who are affected by the disaster, one time the incident is a valuable experience so that they learn from what they have felt. Pandemic COVID-19 is a natural occurrence due to the virus as a way to educate humans about the environment and nature can educate humans to behave in an environmentally friendly manner.

It must be bolstered by Jufri et al., (2019) reveals that environmental education should be based on direct experience with the surrounding environment so that later it is hoped that this direct experience can shape behavior, values, and habits to respect the environment around them. It has similarities with the aim of the education environment. Wulandari \& Amalia, (2018) said that the main objective of environmental education is to change human behavior patterns in society. Cultivating environmental social awareness must be carried out by environmental awareness behavior attached to the individual. Based on interviews with 6 Islamic education students who act as class leaders, there are several nature-based education that provides lessons to humans, including the COVID-19 pandemic teaching humans, especially students and teachers such as lecturers so that they no longer produce waste in nature and process waste properly. Changes in the learning system from face-to-face learning in class have changed human behavior towards digitalization. Meanwhile, the use of digital technology is a step towards life towards zero waste in campus life so that paper waste is no longer produced.

Nuurmayadi \& Hendardi, (2020) reported that garbage itself is referred to as material which, because it has an unfavorable value both economically and environmentally, is finally thrown away. Students and lecturers, as well as educators such as administrative staff only, meet in online and digital media spaces. The Zero Waste concept offers waste management, starting from eliminating waste, recycling, reducing, and restoring used goods (Nizar et al., 2016). With this zero waste concept approach, it emphasizes educating the public to care about the surrounding environment to support economic sustainability, environmental carrying capacity, and social carrying capacity in it. There are several things including maximizing recycling, minimizing waste, making consumption effective, and ensuring that a wasted product can be reused or at least can be recycled so that it can be reduced easily and quickly by nature (Abdullah, 2016). Every time studying online lectures, a lecturer no longer produces waste because he no longer prints documents to give to students so that he applies the principle of reducing (reduce) waste.

Even college assignments ranging from assignments for presentations and practical assignments based on digital documents so that they no longer increase the amount of organic waste in nature. Lecturers also only accept soft files in word and pdf form so that they do not increase the amount of waste. It will directly reduce the use of wood as hard manufacture because the paper is made from wood. Meanwhile, taking wood must cut down trees. When trees are cut down a lot, it affects environmental conditions because trees have a function to stabilize the environment, produce oxygen, and protect the environment from flooding. In addition, the number of documents no longer piles up in the lecturer room and at the student's house due to the large number of documents printed as learning outcomes. This event increases the space usage for the document. When the pandemic disaster came, the lecturers' rooms and student houses no longer increased the number of paper documents. At the same time, waste recycling activities are also reduced. So the COVID-19 pandemic is serious education not to produce waste. Meanwhile, the trash that resides on cellphones and laptop hard drives will not cause problems to the environment. 
The presence of this pandemic has made everyone an agent of change in garbage management. The discovering is encouraged by Arisona, (2018) reveals that in class planting the value of caring for the environment through reducing and reuse activities. Reduce (reduction) can be interpreted as a daily attitude in reducing waste generation, for example limiting paper use by switching to digital. Riali, (2020) remarked that this is in line with efforts to target the Sustainable development goal stating that the country as a whole can reduce waste generation through prevention, reduction, recycling, and reuse. Even efforts to achieve an environmentally friendly campus can be achieved during a pandemic so that it continues in the future. The implementation of digitalization in a learning system at campus leads to abolish the adverse impact of garbage. Negative impacts caused by waste include a decrease in the quality of the environment, either due to pollution or damage to natural resources as well as negative impacts on health, decreased aesthetic value, economic costs, and disruption of the natural system.

Another impact of waste is that it causes health problems, especially waste-borne diseases such as; diarrhea, ARI, skin diseases, malaria, dengue fever, both in the rainy season and the dry season S.m.exposto, (2015). The eco-campus program is motivated by the hope that the campus environment will become a comfortable, clean, shady (green), beautiful and healthy place for students to gain knowledge. Another opinion from the students was that the COVID-19 pandemic taught humans to live to reduce the production of glass emissions as a cause of global warming. When learning is changed through online learning media, lecturers, education staff, and students are being tested to become human beings who are friendly to seasons and climate. Students no longer go to campus so they no longer use vehicles both motorbikes and motorbikes as well as public transportation such as buses and city transportation. Likewise, campus residents no longer use vehicles to come to campus. Whereas before the pandemic, campus residents were included in areas that produced glass emissions because every individual on campus going to campus would use both public transportation and private vehicles.

Kusumawardani \& Navastara, (2018) explain that air pollution caused by the high use of motorized vehicles is in the form of carbon emissions. Carbon emissions, which are increasingly increasing along with the number of motorized vehicles, can harm the environment. Saeful Bahri \& Ziaul Fiqih, (2015) reported that vehicle exhaust emissions contain Hydrocarbon Compound (HC) Emissions, Carbon Monoxide (CO) Emissions, NOx Compound Emissions, Sulfur Oxide (SO2), Black Lead (Lead Dust) (Pb), Carbon Dioxide $(\mathrm{CO} 2)$ which is harmful to the environment and living things. Therefore, as the era progresses, the latest production motor vehicles are designed in such a way as to reduce the number of harmful gases produced from the exhaust gases. The impact of this behavior helps reduce traffic on the road and congestion can be avoided because the number of motorists who go to campus is also reduced. Purwanto, (2015) said that combustion of gasoline and diesel will be more efficient if the car or motorbike is driven at a constant speed, and reduces the frequency of braking and starting. On the other hand, when there is a traffic jam on the road, the combustion of motorized vehicle fuel is no longer perfect, at that time there is a collection of compounds released by motorized vehicles in one place.

As a consequence, a reduction in glass emission gases from the road also occurs. It is not only campus residents who are being taught not to cause problems to the climate but also society at large. Another impact is that parking spaces are no longer congested so that there is plenty of earth space left so that the earth does not appear congested by vehicles. Climate change can also be overcome when the use of electronic devices such as focuses, laptops, and the use of air conditioners (AC) must stop so that emission gases are no longer produced. This finding is supported by the findings of Ismail, (2020) who reported that the number of emission production from university is high. Accumulation of carbon as a caused the emerging of greenhouse gases, leads to jumping the rate of temperature or it can be categorized as global warming which it can refer to as eco-catastrophe. Patrianti et al., (2020) said that the increase in greenhouse gas emissions causes global warming, climate change, and immediate disasters such as high sea levels, extreme weather, floods, landslides, and air pollution. Other 
1610 Education Environment and the Impact of Pandemic Covid-19 in Student Perspective - Bahagia, Fachruddin Majeri Mangunjaya, Rimun Wibowo, Zulkifli Rangkuti

DOI: https://doi.org/10.31004/basicedu.v5i3.957

impacts, such as the threat of global climate change, can not only endanger human health and the environment but also result in a decrease in the environmental quality of residential areas which has exceeded the capacity and carrying capacity of the environment (Indrawati et al., 2015).

The outbreak of Covid-19 has ceased the production of emission because the learning activities must be performed from home and stop face-to-face learning in temporary periods. At the same time, the production of fresh oxygen must be followed by the shortage of vehicles on high roads and campus because people have restricted to go outside from home. As a result, emission and pollution from the car, bus, and motorcycle can be combated. This clean and healthy air has special characteristics that distinguish it from the air that tends to be bad or tends to be polluted. Some of the characteristics of clean and healthy air include colorless, odorless, and tasteless, not mixed with foreign objects, feels fresh when inhaled, feels cool, and can be used for therapy (Agus et al., 2019). Then, the behavior of saving energy and water is a behavior that must grow during a pandemic disaster. Students no longer go to campus so electrical energy is no longer used as energy for lectures and physical teaching practices such as microteaching and lectures as usual. Electrical energy is no longer used to turn on the air conditioner (AC) in every classroom.

Likewise, the use of electronic devices including the use of electric energy by lecturers must be stopped due to lockdown. Activities using electrical energy to turn on computers such as libraries, administration rooms, and study programs and departments are no longer used due to large-scale social restrictions in the early days of the COVID-19 pandemic. Other types of equipment such as printers and photocopier machines as well as electronic equipment such as projector were no longer functional for a while. The problem is, before the COVID-19 outbreak, the energy use in the campus was quite high because the energy consumption was used to turn on facilities, both electronic devices, and room lights, to support student learning. Excessive or wasteful use of electricity we often encounter in people's lives such as lights that are not turned off even though it is morning, lights that are left on while sleeping and in educational entities, we are often found forgetting to turn off the air conditioner after use and LCD projectors that are left on despite activities the lecture has been completed. This can happen because our society is not accustomed to energy-saving behavior, so there needs to be a habit of discipline in using this electrical energy (Utama et al., 2018). Similar to water, campus water is no longer used so that people travel to use water with it wisely. Even though the use of water and electricity was very wasteful when the pandemic had not occurred.

Campus residents are being taught not to overexploit natural resources. A person who is water and energyefficient means that he is learning to manage natural resources sustainably. If it is wasteful in the use of resources, it includes exploitation behavior. The use of water for worship activities such as for wudhu purposes is reduced so that less water is wasted because the water that was used for wudhu has not been reused. The use of other water has also decreased, such as water used for cleaning motorbikes, cars, and watering flowers. There is also less water for other purposes such as cooking and drinking and cleaning bathrooms on campus, likewise, the use of water for cleaning the campus floors and grounds. The arrival of COVID-19 has become a learning method to change water use behavior towards water-saving behavior. Environmental problems such as flooding and drought are forms where humans have not managed water properly. Erlyana, (2017) said that based on research, of the total amount of water on earth, there is only 3\% fresh water. The remaining $97 \%$ is seawater.

We certainly cannot bathe and drink with seawater. Of that small amount, it is said that only $0.62 \%$ is fit for consumption. This means that the amount of water on this earth is very small and limited compared to the increasing amount of water use by humans. The wasteful behavior of clean water causes more and more people to lose access to clean water. Madonna, (2016) said that many ways can be done to save water, including by limiting water use. Meanwhile, according to Kartika, (2019), it is reported that other ways are starting from forming a commitment from top management to fully support the water-saving movement, forming a team of energy and water-saving committees, disseminating employee awareness, detecting water leaks, repairing leaky faucets and meters, damaged water, changing manual faucets to autostop faucets, using dual flush toilets, and 
1611 Education Environment and the Impact of Pandemic Covid-19 in Student Perspective - Bahagia, Fachruddin Majeri Mangunjaya, Rimun Wibowo, Zulkifli Rangkuti

DOI: https://doi.org/10.31004/basicedu.v5i3.957

sprinklers to water plants. Another method used to save water through campus is to save money in wudhu which is adjusted to the method of the Prophet's Sunnah such as. In the hadith narrated by Imam Al-Bukhari received from Anas bin Malik r.a. (He said), "Usually the Prophet SAW., bathed with a bucket of water (one sho), and at most five muds (cupak), and he performed ablution (only) with one mud (cupak) of water (Reported by Iman Al-Bukhari). Unfortunately, religious rules are often neglected so that the use of water for ablution cannot be measured by religious regulations. Ariesman, (2018) said that this is because most of the Muslims are in a water surplus area and do not pay attention to the correct procedures for ablution and do not pay attention to the importance of saving water through ablution. Most of them are wasteful and redundant in using water.

Likewise, with the use of energy, socialization is very necessary to every energy user so that their knowledge can increase to 100 percent for energy saving (Kadir, 2014). Another endeavor that can be implied to reduce the usage of electrical energy is by replacing lighting lamps with energy-efficient lamps (Mukhlis, 2011). After that, the choice of lamp type greatly affects electricity usage. Based on the research of Faridha $\&$ Ifan, (2016), it is reported that the advantages of using LED lights compared to others are that the payment of electricity bills is smaller than incandescent, LHE, and TL lamps. Other findings can also strengthen the above findings where LHE is a source of light because it has soft light (it doesn't hurt the eyes), brighter light, longer life and uses less energy compared to incandescent bulbs. Based on these facts, the use of LHE will have a significant impact in supporting efforts to save energy (Razikin et al., 2012). Other energy observations are supported by the findings of Syamsidarti \& Rahim, (2017) who reported that people can reduce energy consumption in buildings by forming their behavior and habits using electricity when needed, alternately and not excessively, choosing energy-efficient products, and designing energy-efficient buildings. by maximizing natural lighting to reduce the use of lights during the day, maximizing natural ventilation to reduce the use of air conditioning, using roofing materials that can cool the temperature in the room such as earthen or ceramic roofs, placing ornamental plants in the house to cool the air in the room, arrangement landscaping around the building to reduce the increase in micro temperature which will cause an increase in city temperature.

In addition, the campus community is being taught to have a clean and healthy lifestyle when the impact of COVID-19 hits human life. Sari \& Anggoro, (2020) said that one of the factors that affect the condition and cleanliness of the environment is garbage. (Harahap, 2016) said that cleanliness currently defines 4 strategies, namely: Minimizing waste; recycling and composting; improve waste collection services, and waste handling in landfills in an environmentally friendly/friendly manner. During a pandemic, everyone must maintain personal hygiene both body and the environment by regulating themselves in managing various waste in the environment. Students and lecturers, as well as campus educators, will organize themselves to properly process organic waste such as leaves, twigs, and household waste when carrying out activities from home. One of them arranges himself to sort out which waste is organic and inorganic as environmental education to make this behavior a habit. With the emergence of a pandemic, humans are forced to adopt a clean and healthy life. When you come to campus you have to wash your hands and the campus provides a place to wash your hands along with soap.

This clean life is a step towards healthy humans because they live in a dirty environment so that humans are prone to diseases such as bacteria, viruses, and diseases caused by fungi. So some cleanliness must be considered, especially body cleanliness, home environment, the home page, backyard, garden, keeping places of worship clean, and keeping clothes clean. In the cultural aspect, clean behavior contains traditional and religious values. Before COVID-19, Indonesian culture had educated citizens, not only students and lecturers as well as education staff through traditional cleaning activities. Another education that can be felt is fully realizing that humans are unable to master nature with an anthropocentric spirit. Principles and behavior regard humans as the strongest creatures. Humans in nature are not among those who are arrogant in front of the environment like invisible living beings but humans must be aware that they are very weak compared to the parts of nature in this universe. 
1612 Education Environment and the Impact of Pandemic Covid-19 in Student Perspective - Bahagia, Fachruddin Majeri Mangunjaya, Rimun Wibowo, Zulkifli Rangkuti

DOI: https://doi.org/10.31004/basicedu.v5i3.957

For that, humans must maintain an attitude so as not to behave destructively to the environment. This action is very much influenced by how humans perceive nature. If nature is considered an economic commodity only so that nature is only used to meet the needs of human life, its function will be damaged. This function damage causes various disasters such as the COVID-19 disaster caused by a virus, other disasters such as floods, landslides, and drought, including the result of damage to natural functions where humans do. Several factors influence human actions to be environmentally friendly, starting from human awareness, knowledge, and beliefs (Suyud et al., 2020). The incidence of COVID-19 proves that humans must submit to nature because this vision is part of the natural environment or the biotic environment (living things). Everyone is currently afraid of the Coronavirus, everyone wears a mask and wears a face shield when going out of the house. Some even choose to stay at home as a step to avoid spreading and getting infected by other people. The effect of this problem makes humans have to apply friendly principles and behavior and change their perspective to interpret nature.

Two views can be achieved during a pandemic like this, namely the view of biocentrism and the view of eco-centrism but to stop the view of anthropocentrism. These two views can form an environmentally friendly human character. Even humans are being taught literacy and disaster mitigation. Mitigation includes efforts carried out before and after a disaster occurs. In disaster mitigation, preparedness before a disaster occurs must have been carried out starting from foodstuff reserves and the most effective control methods. The emerging of COVID-9 in the human environment. In addition, there are many impacts on students, especially from various social, religious, and psychological aspects of students. COVID-19 teaches humans to always be vigilant in the face of possible dangers and natural disasters. The problem is, efforts are sometimes forgotten so that disaster occurs first, so control measures are taken. Every disaster such as the COVID-19 outbreak, no human knows about the arrival of this disaster. It is even worse if there is no adequate food preparation, medical personnel, and health facilities to cope with disasters. Natural selection is one way that is done naturally today where the pandemic tries to find humans who pass the natural test.

Natural selection is natural that tests humans with environmental conditions that are not suitable for humans. Some pass this test and some who don't, someone who does not pass will be affected but can be healthy again. However, some are not strong with the selection so they do not qualify. Nonetheless, tests like this are carried out to see to what extent humans are patient to face natural selection as well as what actions are being taken to be free from the test. That is, humans are currently being schooled by nature to graduate from school. One day, something that was difficult will be the happiest part of life even though it is very difficult to pass this test. Student social problems include damaged social relations between students, they are no longer able to establish friendship in a face-to-face manner to reduce the sense of kinship. Student social relations have shifted from face-to-face to the world of digitalization. Students must learn how to operate various digital media such as WhatsApp, google meet, zoom, and other online media as a medium for interacting with peers and lecturers during college.

This incident made students literate and study digital media as an adaptation step. This means that students adapt to new behaviors so that they can continue to function learning and social life in the campus environment in the digital space where they have been in the classroom. The positive impact is that they are not left behind with learning technology. The negative impact, students do not know other students, especially in terms of behaviour, whereas the introduction of attitudes and behavior of other students is very necessary to be able to foster social skills when joining a very complex social environment with differences in religion, ethnicity, and culture. Student health is also affected. The presence of zoom space and too much use of gadgets can cause physical health problems due to exposure to signals from mobile phones. This situation was exacerbated again by disrupted congregational worship, religious activities at the campus were also disrupted, and student organization activities could not be carried out. Meanwhile, religion serves as a shield for students to increase their moral values. 
1613 Education Environment and the Impact of Pandemic Covid-19 in Student Perspective - Bahagia, Fachruddin Majeri Mangunjaya, Rimun Wibowo, Zulkifli Rangkuti

DOI: https://doi.org/10.31004/basicedu.v5i3.957

Simultaneously, the memorization of the sacred texts of the Koran is also disrupted due to the limitations of digital media. Finally, the psychological condition of students is also disturbed because they experience stress due to environmental situations where there are limitations to going out of the house, cannot visit friends, and cannot joke with classmates. It can be exacerbated by the online learning system to then the student has more stress for confronting the class. In fact, in completing assignments from lecturers, the students confront some obstacle including several subjects of a lecture requires to discuss face-to-face. It leads to a heavy burden because the task must be completed but the covid-19 catastrophe makes the student unable to finish the duty from the lecturer. As result, the student can obtain a low value in that homework. Even students face precarious circumstances because they can't discuss properly through some learning media. After all, sometimes the signal of mobile phone doesn't work clearly.

\section{CONCLUSION}

Based on the results above, it can be concluded that several important parts include the class leaders of semester VI students who have the view that the COVID-19 outbreak provides learning to humans to behave in an environmentally and climate-friendly manner. Students get environmental education in the presence of the COVID-19 disaster because students think that with the outbreak, students no longer go to campus so they no longer use private vehicles, both motorbikes, and cars. Likewise, students who use public vehicles are no longer used because the learning system is no longer face-to-face but has changed to learning from home using various online media. As a consequence, the production of gas emissions as a cause of global warming and climate change can be overcome temporarily. Even so, this method is an educational experience to behave friendly to the environment and the climate in the future. In addition, the general public participates because the community also reduces emissions due to social restrictions and requires people to stay at home. Directly, people are organizing themselves to care for the environment to regulate their behavior so that it does not produce much pollution.

The adaptation of an online learning system that includes WhatsApp, google meet, zoom and video reduces waste production. Even though the production of organic waste through learning on campus is quite high, the lecturers always give assignments to students where the assignment documents must be printed. Once the value is given by the lecturer, the document becomes trash. Another environmental education is increasing awareness and awareness of the importance of environmental cleanliness in students. Students are being taught to maintain cleanliness because a new behavior appears during a pandemic, namely the habit of washing hands. Another habit that grows is the temper to maintain physical cleanliness, home yards, places of worship, and campuses because cleanliness is a way to control the COVID-19 outbreak. In addition, the covid-19 outbreak that hit students and campuses has made the campus world an example of saving energy and water. The COVID19 outbreak has forced humans to save energy from campus for various purposes such as electricity used for projector, office equipment, air conditioners, photocopier machines, and other protective electronic devices.

All of the campus tools and facilities use up electrical energy so that the arrival of COVID-19 fosters an energy-saving attitude. This is the case with the use of water on campus, water is no longer used for a while starting from water for bathroom, washing, cooking, and ablution. So far, the remaining ablution water is only thrown away, but in the future, it will be processed because it has been stimulated so that you realize that water is a very important resource. Then, humans are being taught not to go against nature and humans are very weak compared to the very strong forces of nature. This learning makes humans aware that humans must be wise and not fight against the forces of nature. It is even part of the natural selection carried out by the environment because the coronavirus is part of the living environment. Whoever passes the natural selection will also pass the test conducted directly by nature. Another impact is that students have difficulty establishing social relationships because they never meet face to face. Meanwhile, to understand and study behavior between students, adaptation is needed by meeting them. The arrival of COVID-19 made students experience difficulties. 
1614 Education Environment and the Impact of Pandemic Covid-19 in Student Perspective - Bahagia, Fachruddin Majeri Mangunjaya, Rimun Wibowo, Zulkifli Rangkuti

DOI: https://doi.org/10.31004/basicedu.v5i3.957

This is exacerbated by the fact that students are no longer able to carry out normal worship services at the campus such as recitation and congregational activities. Psychologically, students also experience stress because learning is always online and there are social restrictions.

\section{REFERENCES}

Abdullah, M. R. (2016). Rusunami Arjuna Eco-Housing dengan Pendekatan Zero Waste Concept. Jurnal Reka Karsa, Jurnal Online Intstitut Teknologi Nasional, 1-11.

Agus, A., Ahmad, M., Kusumaningtyas, S. D. A., Nurhayati, H., Khoir, A. N., \& Sucianingsih, C. (2019). Analisis Dampak Diterapkannya Kebijakan Working From Home Saat Pandemi Covid-19 Terhadap Kondisi Kualitas Udara Di Jakarta. Jurnal Meteorologi Klimatologi Dan Geofisika, 6(3), 6-14.

Agustin, A. V. (2018). Penerapan Green Office di Kantor Pelayanan Perbendaharaan Negara Jakarta III. Jurnal Utilitas, 4(1), 9-15.

Angelica, H., \& Hemme, T. E. (2021). Stres Dan Koping Mahasiswa Keperawatan Selama Pembelajaran Daring Di Masa Pandemik Covid-19. Jurnal Ilmiah Keperawatan Imelda, 7(1), 28-34.

Ankit, Kumar, A., Jain, V., Deovanshi, A., Lepcha, A., Das, C., Bauddh, K., \& Srivastava, S. (2021). Environmental impact of COVID-19 pandemic: more negatives than positives. Environmental Sustainability. https://doi.org/10.1007/s42398-021-00159-9

Ariesman, M. (2018). Efisiensi Air Di Pesantren Melaui Penerapan Sunnah Nabi Dan Teknologi Terapan. NUKHBATUL'ULUM: Jurnal Bidang Kajian Islam, 4(1), 40-50.

Arisona, R. D. (2018). Pengelolaan Sampah 3r (Reduce, Reuse, Recycle) Pada Pembelajaran Ips Untuk Menumbuhkan Karakter Peduli Lingkungan. Al Ulya: Jurnal Pendidikan Islam, 3(1), 39-51.

Bertram, C., Luderer, G., Creutzig, F., Bauer, N., Ueckerdt, F., Malik, A., \& Edenhofer, O. (2021). COVID-19induced low power demand and market forces starkly reduce $\mathrm{CO} 2$ emissions. Nature Climate Change, 193-196. https://doi.org/10.1038/s41558-021-00987-х

Bolaño-Ortiz, T. R., Puliafito, S. E., Berná-Peña, L. L., Pascual-Flores, R. M., Urquiza, J., \& Camargo-Caicedo, Y. (2020). Atmospheric emission changes and their economic impacts during the COVID-19 pandemic lockdown in Argentina. Sustainability (Switzerland). https://doi.org/10.3390/su12208661

Chapman, A., \& Tsuji, T. (2020). Impacts of COVID-19 on a transitioning energy system, society, and international cooperation. In Sustainability (Switzerland). https://doi.org/10.3390/su12198232

El Zowalaty, M. E., Young, S. G., \& Järhult, J. D. (2020). Environmental impact of the COVID-19 pandemica lesson for the future. In Infection Ecology and Epidemiology (pp. 1-3). https://doi.org/10.1080/20008686.2020.1768023

Erlyana, Y. (2017). Kajian Kampanye Sosial Hemat Air. Rupa Rupa, 4(2).

Faridha, M., \& Ifan, I. (2016). Studi Komparasi Lampu Pijar, Led, Lhe Dan Tl Yang Ada Dipasaran Terhadap Energi Yang Terpakai. Al-Jazari Jurnal Ilmiah Teknik Mesin, 1(2).

Fernando, \& Guspa, A. (2021). Tingkah Perilaku Konsumtif Online Shopping di Masa Pandemi pada Mahasiswa Universitas Negeri Padang. Socio Humanus, 3(1), 66-75.

Harahap, R. D. (2016). Pengaruh Sampah Rumah Tangga Terhadap Pelestarian Lingkungan Ditinjau Dari Aspek Biologi Di Komplek Perumahan Graha Pertiwi Kel. Urung Kompas Kec. Rantau Selatan Effect Of Household Waste Viewed From The Aspect Environmental Conservation Biology In Housin. Cahaya Pendidikan, 2(1), 92-104. https://doi.org/10.33373/chypend.v2i1.609

Indrawati, E. D., Hermawan, H., \& Huboyo, H. S. (2015). Analisis Emisi Co2 Antropogenik Rumah Tangga Di Kelurahan Patukangan, Pekauman Dan Balok, Kabupaten Kendal. Indonesian Journal of Conservation, 04(1), 45-51.

Ipin, A. (2017). Pembelajaran Pendidikan Lingkungan Hidup Berorientasi 3R (Reuse, Reduce and Recycle) 
1615 Education Environment and the Impact of Pandemic Covid-19 in Student Perspective - Bahagia, Fachruddin Majeri Mangunjaya, Rimun Wibowo, Zulkifli Rangkuti

DOI: https://doi.org/10.31004/basicedu.v5i3.957

Untuk Meningkatkan Kreativitas Dan Sikap Peduli Lingkungan. Bio Educatio, 2(2), 01-11.

Ismail, A. (2020). Potensi Penurunan Emisi Gas Rumah Kaca (Grk) Dalam Kegiatan Belajar Di Rumah Secara On-Line: Analisis Jejak Karbon (Carbon Footprint Analysis). Jukung (Jurnal Teknik Lingkungan), 6(2), 195-203. https://doi.org/10.20527/jukung.v6i2.9262

Jannah, R. (2021). Tingkat Stres Mahasiswa Mengikuti Pembelajaran Daring pada Masa Pandemi Covid-19. In Jurnal Riset dan Pengabdian Masyarakat.

Jufri, Fua, J. La, \& Nurlila, R. U. (2019). Pendidikan Lingkungan Di Sekolah Dasar Negeri 1 Baruga Kota Kendari. Al-TA'DIB: Jurnal Kajian Ilmu Kependidikan, 164-181.

Kadir, M. Z. (2014). Sosialisasi Tata Cara Menghemat Penggunaan Energi Listrik Pada Pengelolaan Peralatan Dan Ruang Pada Beberapa Sekolah Di Sekitar Inderalaya Kabupaten Ogan Ilir. Jurnal Pengabdian Sriwijaya, 2(2), 111-116. https://doi.org/10.37061/jps.v2i2.1602

Kartika, S. A. (2019). Evaluasi Penerapan Program Penghematan Air Bersih di Gedung Perkantoran (Studi Kasus Penghematan Air Bersih di Gedung Perkantoran PT TEPI). JTT (Jurnal Teknologi Terpadu), 7(1), 38-44. https://doi.org/10.32487/jtt.v7i1.623

Kusumawardani, D., \& Navastara, A. M. (2018). Analisis Besaran Emisi Gas CO2 Kendaraan Bermotor Pada Kawasan Industri SIER Surabaya. Jurnal Teknik ITS, 6(2), 2337-3520. https://doi.org/10.12962/j23373539.v6i2.24392

Linarwati, M., Fathoni, A., and Minarsih, M. M. (2016). Studi deskriptif pelatihan dan pengembangan sumberdaya manusia serta penggunaan metode behavioral event interview dalam merekrut karyawan baru di bank mega cabang kudus. Journal Of Management, 2(2).

Lubis, H., Ramadhani, A., \& Rasyid, M. (2021). Stres Akademik Mahasiswa dalam Melaksanakan Kuliah Daring Selama Masa Pandemi Covid 19. Jurnal Psikologi 10 (1):31-39. http://dx.doi.org/10.30872/psikostudia.v10i1.5454

Madonna, S. (2016). Efisiensi Energi Melalui Penghematan Penggunaan Air (Studi Kasus: Institusi Pendidikan Tinggi Universitas Bakrie). Jurnal Teknik Sipil, 12(4), 267-274. https://doi.org/10.24002/jts.v12i4.635

Mukhlis, B. (2011). Penghematan Energi Melalui Penggantian Lampu Penerangan Di Lingkungan Untad. Jurnal Ilmiah Foristek, 1(2).

Nizar, M., Munir, E., \& Munawar, E. (2016). Manajemen Pengelolaan Sampah Kota Berdasarkan Konsep Zero Waste : Studi Literatur. Pengabdian Kepada Masyarakat, 1(2), 93-102.

Noviarini, T. (2021). Dampak Pandemi Covid-19 Terhadap Sikap Pembelajaran Bahasa Pada Mahasiswa Universitas Mitra Karya Bekasi. Jurnal Ilmiah Wahana Pendidikan, 7(1), 75-81.

Nurdin, I., \& Hartati, S. (2019). Metodologi Penelitian Sosial. Media Sahabat Cendekia.

Nuurmayadi, D., \& Hendardi, A. R. (2020). Pengelolaan Sampah Dengan Pendekatan Behavior Mapping Di Pasar Tradisional Kota Tasikmalaya. Jurnal Arsitektur Zonasi, 3(1), 45-52. https://doi.org/10.17509/jaz.v3i1.21737

Patrianti, T., Shabana, A., \& Tuti, R. W. (2020). Komunikasi Risiko Pemerintah Pada Penurunan Emisi Gas Rumah Kaca Untuk Mengatasi Perubahan Iklim Government Risk Communication On Greenhouse Gas Emission Reduction To Tackle Climate Change. Jurnal Penelitian Komunikasi Dan Opini Publik, 24(2), 156-170.

Priyono. (2016). Metode Penelitian Kuantitatif. Sidoarjo: Zifatama Publishing.

Purwanto, C. P. (2015). Inventarisasi Emisi Sumber Bergerak Di Jalan (On Road) Kota Denpasar. Ecotrophic: Jurnal Ilmu Lingkungan (Journal of Environmental Science), 9(1), 1-9. https://doi.org/10.24843/ejes.2015.v09.i01.p01

Ratunuman, R. A., David, L. E. V., \& Opod, H. (2021). Dampak Psikologis Pandemi COVID-19 Pada Mahasiswa. Jurnal Biomedik, 13(2), 227-232. 
1616 Education Environment and the Impact of Pandemic Covid-19 in Student Perspective - Bahagia, Fachruddin Majeri Mangunjaya, Rimun Wibowo, Zulkifli Rangkuti

DOI: https://doi.org/10.31004/basicedu.v5i3.957

Razikin, A., Syaifurrahman, \& Islami, J. (2012). Perbandingan Unjuk Kerja Lampu Hemat Energi ( LHE ) Bergaransi dan Tidak Bergaransi. Jurnal ELKHA, 4(1), 7-10.

Riali, M. (2020). Pengelolaan Sampah Kota Berdasarkan Konsep Zero Waste. Pondasi, 25(1), 25-186. https://doi.org/10.30659/pondasi.v25i1.13037

Rukminingsih, Adnan, G., \& Latief, M. A. (2020). Metode Penelitian Pendidikan. Penelitian Kuantitatif, Penelitian Kualitatif, Penelitian Tindakan Kelas. In Journal of Chemical Information and Modeling.

Rume, T., \& Islam, S. M. D. U. (2020). Environmental effects of COVID-19 pandemic and potential strategies of sustainability. In Heliyon. https://doi.org/10.1016/j.heliyon.2020.e04965

S.m.exposto, L. (2015). Pengaruh Pengelolaan Sistem Pembuangan Akhir Sampah Dan Dampak Terhadap Kesehatan Masyarakat Di Desa Tibar, Kecamatan Bazartete, Kabupaten Liquiça, Timor-Leste. Bumi Lestari, 15(2), 115-124.

Saeful Bahri, \& Ziaul Fiqih. (2015). Rancang Bangun Alat Ukur Emisi Pada Gas Buang Kendaraan Bermotor Berbasis Mikrokontroler. Jurnal ELEKTUM, 12(1), 1-13.

Santoso, R. (2021). Pengaruh Motivasi dan Sarana Belajar Online Terhadap Kemandirian Belajar Mahasiswa FEB Institut Asia di Masa Pandemi Covid-19. Jurnal Pendidikan Ekonomi, 14(1), 25-36.

Sari, C. K., \& Anggoro, S. (2020). Edukasi Dampak Pengelolaan Sampah sebagai Upaya Peningkatan Pemahaman Siswa tentang Gerakan Masyarakat Hidup Sehat. Jurnal Peduli Masyarakat, 2(2), 41-48. https://doi.org/10.37287/jpm.v2i2.91

Setyobudi, F., \& Marsudi, S. (2018). Pendidikan Lingkungan Hidup Di Smp Negeri 3 Kebumen Jawa Tengah. JIPSINDO, 1(5), 1-20. https://doi.org/10.21831/jipsindo.v5i1.20180

Shakil, M. H., Munim, Z. H., Tasnia, M., \& Sarowar, S. (2020). COVID-19 and the environment: A critical review and research agenda. Science of the Total Environment.

https://doi.org/10.1016/j.scitotenv.2020.141022

Sya'ban, Moh, A. (2018). Tinjauan mata pelajaran IPS SMP pada penerapan pendidikan lingungan hidup untuk peduli akan tanggung jawab lingkungan. Jurnal Geografi, Edukasi Dan Lingkungan (JGEL)2, 2(1), 32 44.

Syamsidarti, S., \& Rahim, M. (2017). Penghematan Biaya Rutin Dan Biaya Operasional Pada Bangunan Rumah Tinggal. Humano: Jurnal Penelitian, 7(1), 104-112.

Solikhah, N., \& Suripah. (2021). Dampak Covid-19 Terhadap Implementasi Pembelajaran Bahasa Inggris Secara Mandiri Dalam Perkuliahan Jarak Jauh (Daring) Di Tingkat Perguruan Tinggi. Jurnal Education And Development 9 (1):57-61.

Utama, A. G. S., Janani, N. M., Silfiana, S., Wulandari, T. N. A., \& Budiningtyas, B. (2018). Automation Of Electrical Energy Savings System: Hemat Listrik, Hemat Biaya. Ekuitas: Jurnal Pendidikan Ekonomi, 6(2), 79-87. https://doi.org/10.23887/ekuitas.v6i2.16303

Wulandari, P. A., \& Amalia, N. A. (2018). Pendidikan Lingkungan Hidup Dan Pembelajaran Ips Di Sekolah Dasar Sebagai Alternatif Penanaman Kesadaran Lingkungan. In FKIP e-PROCEEDING (pp. 36-43). 